\title{
Legal Regulation as Driver for Sustainable Development of Nigeria's Solid Mineral Sector
}

Isaac Onyeyirichukwu Chukwuma ${ }^{1}$, Benjamin Onoriode Mukoro ${ }^{1}$, Fidelis Odinakachukwu Alaefule ${ }^{1}$, Gertrude Chinelo Ugwuja ${ }^{1}$, Emmanuel Kalu Agbaeze*,1, Ifeanyi Leo Madu²

${ }^{1}$ University of Nigeria, Department of Management, Nigeria

${ }^{2}$ Gregory University, Department of Business Administration, Nigeria

\section{A R T I C L E I N F O}

Article history:

Received: 01 January, 2020

Accepted: 22 February, 2020

Online: 24 April, 2020

Keywords:

Legal regulation

Sustainable development

Solid mineral

\begin{abstract}
A B S T R A C T
The need to optimally explore Nigeria's diverse mineral resource endowments via sustainable value chain practices has, in recent times, been the focus of the Nigerian government and relevant stakeholders. This development has amongst other things, been made a necessity since the decline in Nigeria's crude oil export and earnings, as well as the increased effort and commitment of the government to significantly diversify the economy from reliance on agriculture and the oil and gas sectors. This challenge has directed government efforts towards promoting the exploration of the solid mineral sector, to leverage its opportunities to attract investors and further sustainable development. The concept of sustainable development demands that economic ventures be both viable and environmentally sustainable. As a result of the self-seeking ethos of market economies, it is often necessary for the law to step in to moderate the profitoriented tendencies of commercial interest. The paper aims to examine the sustainable development of Nigeria's solid mineral sector through legal intervention. The objectives are to:(i) determine the importance of law to the sustainable development of Nigeria's solid mineral sector;(ii) ascertain the current provisions of laws and policies in relation to the operation of the solid mineral sector and their impact on the sustainable development of the sector and (iii) make informed recommendations on how to use law as a tool to promote the sustainable development of Nigeria's solid mineral sector. This study employed a qualitative approach in examining how well the current legal framework governing the solid mineral sector in Nigeria is positioned to promote sustainable development. It was found that the major impediments to the sustainable development of the solid mineral sector in Nigeria are centralization of ownership and resultant alienation of communities, restiveness in alienated communities, poor administrative infrastructure and implementation of laws and policies, and corruption.
\end{abstract}

\section{Introduction}

The need to optimally exploit Nigeria's diversified mineral resource endowments via sustainable value chain practices has, in recent times, been the focus of the Nigerian government and relevant stakeholders. This development has, amongst other things, been made a necessity since the decline in Nigeria's crude oil export and earnings, as well as the increased effort and commitment of the government to significantly diversify the

${ }^{*}$ Corresponding Author: Emmanuel Kalu Agbaeze, University of Nigeria, emmanuel.agbaeze@unn.edu.ng

www.astesj.com

https://dx.doi.org/10.25046/aj050296 economy from reliance on agriculture and oil and gas sector [1] This challenge or gap created has directed government efforts in promoting the exploration of the solid mineral sector, to leverage its opportunities to attract investors and further sustainable economic development.

The Nigerian government over time has built a framework that not only attracts but also secures and emboldens investors to explore the economic potentials embedded in the solid mineral sector; this was achieved via the diverse legal apparatus and reforms institutionalized by the government (i.e. Development 


\section{I.O. Chukwuma et al. / Advances in Science, Technology and Engineering Systems Journal Vol. 5, No. 2, 769-773 (2020)}

of the Nigerian Minerals and Mining Act, 2007; Development of the National Minerals and Metals Policy, 2008; Development of the Nigerian Minerals and Mining Regulations, 2011; Establishment of the Mining Cadastre Office (MCO) for mineral rights management; Establishment of the Nigerian Institute of Mining and Geosciences (NIMG); Enhanced geoscience data collection across Nigeria; Establishment of control departments for Mines Environmental Compliance and Artisanal and Small Scale Mining), and strategically tailored to stimulate best practices, as well as avoid the pitfalls that marred exploitation of mineral deposits in the past; nonetheless, the validity of this legal framework within the Nigerian context is yet to produce a concrete result within the scope of sustainable economic development.

There is extant literature on the concept of sustainable development and equivocalness in the definition of the concept; extrapolating the definition by the World Commission on Environment and Development [2], sustainable development is the development that meets the needs of the present without compromising the ability of future generations to meet their own needs. Within the Nigerian context, achieving a sustainable development connotes a real, positive and tangible development that is acknowledged by the diverse populace. The need for a viable, sustainable development in Nigeria is eminently required as it continues to face socio-economic challenges as well as domestic and foreign constraints [3], hence opportunities present within the solid mineral sector are projected for the world to see and exploit [4], as a tool to the furtherance of the Nigerian sustainable development agenda.

The paper aims to examine the sustainable development of Nigeria's solid mineral sector through legal intervention. Section 2 of the paper looks at the issues and challenges experienced in Nigeria's solid mineral sector. Section 3 discusses the role of law in the sustainable development of the sector. Section 4 evaluates how effective regulation of the solid mineral sector has been and the sustainable development potentials of effective legal regulation. Section 5 examines the construct within the dynamic capabilities theory. Section 6 proffers recommendations to promote sustainable development in the solid mineral sector.

\section{The Mining Sector in Nigeria: Issues and Challenges}

The trajectory of the Nigerian mining sector was firmly pioneered by Britain's colonial economic exploration dating back to 1902; this exploration then moved to a private sectorfocused model, and to an epoch of government-controlled operations at which Nigeria's' earning from mining was a major revenue base, and mining was the leading employer of labour until the discovery of oil, at which point the mining sector was greatly neglected [5-7].

Notwithstanding the advantages in the oil sector, the keen focus on the sector by the government at the expense of other sectors (i.e. solid mineral sector) is blamed for the moribund state of these other sectors [7-8]. The long years of focus on hydrocarbon resources had neglected the overwhelming endowments Nigeria possesses in the solid minerals sector [5], which is mostly under-developed notwithstanding its glorious past and its present potential to sustain the desired development.

Presently, the Nigerian government has shown a keen interest and commitment to the diversification agenda and actively plays a key role in ensuring the development of other sectors (i.e. solid mineral sector) as a driver for sustainable development. The minerals are classified as

i. Industrial minerals (e.g. barite, kaolin, gypsum, feldspar, limestone).

ii. Energy minerals (e.g. bitumen, lignite, uranium).

iii. Metallic ore minerals (e.g. gold, cassiterite, columbite, iron ore, lead-zinc, copper).

iv. Construction minerals (e.g. granite, gravel, laterite, sand).

v. Precious stones (e.g. sapphire, tourmaline, emerald, topaz, amethyst, garnet, etc.).

Nigeria is known as a nation that is abundantly endowed with diverse solid mineral deposits that are valuable and explorable in the world [5]. The presence of these deposits has been the focus of economic attraction for both formal and informal mining activities; the solid minerals sector is capable of generating employment and creating wealth for over five million people [9]. The sector's contribution to GDP averaged 0.37 percent in 20112012 to over 12 percent in 2012-2013 [9], possessing a doubledigit growth rate, evidence that the sector can sustain Nigeria from the intricacies of the oil saga and economic uncertainties.

Notwithstanding the projected potentials inherent in the exploration of solid minerals, and the legal leverages provided by the government in exploring it to achieve sustainable development, the following have been noted as constraints to this achievement [5, 10-11]:

i. Insufficient geoscience data and information.

ii. Inadequate infrastructure and support systems for investors' activities.

iii. A decline in stakeholders' interest.

iv. Weak Institutions and governance structure.

v. Laxity in regulation enforcement.

vi. Ecological mismanagement.

vii. Activities of informal miners.

A common issue in this endowment of solid minerals across Nigeria is the ease of accessibility by any interested party, and this, the legal regulation seeks to formalize.

\section{The Role of Law}

\subsection{The Twin Imperatives of Economic Viability and Sustainability}

The concept of sustainable development demands that economic ventures be both viable and environmentally sustainable. As a result of the self-seeking ethos of market economies, it is often necessary for the law to step in to moderate the profit-oriented tendencies of commercial interests. In Nigeria, this has been done primarily by coordinating the powers of the Federal 
Ministry of Mines and Steel Development and the Federal Ministry of Environment. The Federal Ministry of Mines and Steel Development administers the Minerals and Mining Act (MMA), 2007, the Minerals and Mining Regulations (MMR) 2011, and three policy documents: the National Minerals and Metals Policy 2008, the Vision 2020 Report of the National Technical Working Group on Minerals and Metals Development, and the Roadmap for the Development of the Solid Minerals and Metals Sector. The Federal Ministry of Environment, on its part, administers the National Environmental Standards and Regulations Enforcement Agency (NESREA) Act.

According to a UNDP Sourcebook [12], mining activities can contribute to sustainable development, particularly to its economic dimension. It can generate fiscal revenues to a nation, increase economic growth, create jobs, and contribute to building infrastructure. Thus, mining has both positive and negative implications for sustainable development goals (SDGs) with particularly strong impacts on goal 11 and 17 . The question that arises from this double-edged nature of mining in the Nigerian context is; how properly-suited are Nigerian laws to creating a balance between economic and environmental interests? Can these laws ensure the optimal harnessing of the economic potentials of the mining sector while at the same time providing protection and incentives for the prosperity of the environment? Are there investment incentives in place to encourage investment in the solid mineral sector? How are problems such as illegal mining that lead to both revenue leakage and environmental degradation addressed?

\subsection{The Legal Framework}

The Minerals and Mining Act 2007 is the primary statute governing mining activities in Nigeria. The Act contains some incentives for prospective investors in the mining sector. For example, a company granted a mineral title is entitled to tax relief for three years from the date of commencement of operation, which may extend for another two years subject to specified conditions. Operators in the mining sector are also granted exemption from the payment of customs and import duties in respect of plant, machinery, equipment, and accessories imported specifically and exclusively for mining operations [13]. The Industrial Development (Income Tax Relief) Act contains similar incentives. These incentives cover minerals such as lead, zinc, iron, barytes, bentonites, gold, coal, bitumen, and associated minerals [14].

The Companies' Income Tax Act (CITA) provides that a new company going into mining of solid minerals will be exempted from tax for the first three years of its operations. Additional incentives in CITA include a reduced tax rate of $20 \%$ for Nigerian companies which earn a total gross turnover of less than a million naira after commencement of business, accelerated capital allowances at $95 \%$ initial allowance, exemption of profits from corporate tax where minerals produced are exported from Nigeria, and the proceeds from such exports are repatriated to Nigeria and used exclusively for the purchase of raw materials, plants, equipment, and spare parts. There is also zero-rating for value-added tax (VAT) purposes for Nigerian mining companies [14].
As regards the protection of the environment, the Minerals and Mining Regulations mandate mineral title holders to carry out an environmental impact assessment and submit environmental impact assessment statement. They are also required to put in place environmental protection and rehabilitation programmes and have a community development agreement with host communities [15]. There are provisions targeted at particular aspects of the environment. For example, there are provisions relating to the protection of biodiversity, national parks, cultural heritage and sanctuaries, endangered species, etc. [15]. The Regulations also provide broad supervisory powers to the Mines Environmental Compliance Department including the power to inspect mines and the arrangements for disposal of different forms of waste including water and tailings [15].

Apart from the environmental protections contained in MMA, which relate specifically to the solid mineral sector, the NESREA Act, 2007, includes provisions relating to the protection of the environment in general. NESREA has also developed thirty-three Environmental Regulations. Among these are the National Environmental (Mining and Processing of Coal, Ores and Industrial Minerals) Regulations 2009, National Environmental (Base Metals, Iron and Steel Manufacturing/Recycling Industries) Regulations 2011, National Environmental (Non-Metallic Minerals Manufacturing Industries Sector) Regulations 2011, and the National Environmental (Quarrying and Blasting Operations) Regulations 2013. The NESREA Act and Regulations contain stipulations that are very relevant to the protection of the Nigerian environment.

\section{Regulatory Challenges and the Potentials of Effective Regulation}

There are two common ways in which any regulatory framework may be deficient. Deficiency may exist in terms of the material provisions of legal documents or their implementation. In Nigeria, problems exist in both of these segments. As regards the letter of laws and policies, while a lot has been done to enact laws suitable to the advancement of the solid mineral sector, there is fundamental legal-structural incongruence that has to be rectified for super-structural legal changes to achieve their maximum effect. Concerning the legal/structural foundation of the solid mineral sector, two Nigerian Constitution statutes, the Land Use Act, 1978, and the MMA, 2007, come to mind. Section 44(3) of the 1999 Constitution vests title in all minerals found anywhere in the country on the Federal Government. The Land Use Act vests title in all the lands in a state in the Governor [16]. The Government may acquire lands with minimal compensation to the original owners for overriding public interest including for mineral exploitation by the Federal Government [16]. This practice alienates the host communities and leads to noncooperativeness and instability that, in turn, affects the rate of investment in the sector.

Section 1 of MMA provides that the entire property in and control of all Mineral Resources in, under or upon any land in Nigeria, its contiguous continental shelf and all rivers, streams, and watercourses throughout Nigeria, any area covered by its 
territorial waters or constituency and the exclusive economic zone is and shall be vested in the Federation for and on behalf of the people. Section 2 provides that the government of the federation shall from the commencement of this Act acquire all lands in which minerals have been found in commercial quantities under the provisions of the Land Use Act. As has been said concerning the Land Use Act, regulations like these lead to resentment among host communities who believe that is their right to the minerals found in their ancestral lands. This feeling of oppression and exclusion promotes non-cooperation and parallel exploitation of mineral resources by members of host communities, whether alone or in conjunction with outsiders. Parallel exploitation of mineral resources is illegal according to applicable laws, and very importantly, it leads to revenue leakage and environmental damage. While the government has tried to tackle the problem of illegal mining by providing for the grant of leases for artisanal and small-scale mining, it is not always easy for artisanal and small-scale miners to obtain these leases. Mineral titles may be granted to individual artisanal and small-scale miners as well as co-operatives. However, in reality, assistance to artisanal and small-scale miners has been through miners' co-operatives whose total membership does not embrace the greater majority of miners who remain unregistered and unregulated.

Apart from the legal-structural challenges mentioned above, there is the problem of poor implementation that generally plagues laws and policies in Nigeria, and this has also affected the solid mineral sector. Thus, environmental standards are routinely flouted and mostly without consequences for the offenders, and host communities do not get involved in the fight against environmental degradation as they should due to a combination of factors, for instance, the alienation mentioned above when combined with poverty and lack of awareness. Another reason for poor implementation of environmental standards is that relevant regulatory and enforcement institutions often do not have the capacity (technological and otherwise) to carry out enforcement.

The challenge of poor implementation is also sharply felt with regard to the administration of investment incentives. It is common to experience corrupt practices in the implementation of incentives as entities not qualified to enjoy incentives often access them fraudulently. At times, where a beneficiary's due period of enjoyment has elapsed for some reason, they find fraudulent ways to prolong their enjoyment of incentives. This means that those who need these incentives may not get them. It is also helpful to note that apart from the problems particularly associated with investment incentives in Nigeria, there are general questions related to the efficacy of tax incentives specifically, which are not peculiar to Nigeria. The positive theoretical effect of tax incentives has been questioned, and governments have used different models such as the Computable General Equilibrium (CGE) to conduct a cost-benefit analysis to ascertain their economic and revenue impact [17].

\section{Dynamic Capabilities Theory (DCT) Perspective}

The DCT explores how sustainable advantage is achieved; [18] argues that successful nations in the global market place can demonstrate timely responsiveness to market changes and speedy product innovation. Also, successful nations can optimally coordinate and reorganize internal and external resources; hence the increased effort and commitment of the Nigerian government to significantly diversify the economy from reliance on agriculture and the oil and gas sectors [1]. The ability to achieve a sustainable advantage in this context is referred to as the Dynamic Capabilities [18]. The term "dynamic" connotes the capacity to utilize resources to attain congruence with the changing business environment and national interest; this is relevant in a situation where values on resources (i.e. crude oil) are constantly evolving and unpredictable. Capabilities connote the crucial role of strategic management in suitably adapting, integrating and reconfiguring, internal and external national skills, resources, and functional competencies to fit the needs of a changing environment [18]. The theory postulates that the way nations develop sustainable development is to respond to changes in the global environment, and the optimality of this sustainable development is anchored on a nation's processes, market positions, and opportunities [18].

\section{Recommendations and Conclusion}

There has been an overwhelming argument in support of the need to amend section 44(3) of the Nigerian Constitution and to repeal the Land Use Act, and this paper supports that argument. The Constitution and Act should be amended and repealed alongside the statutory and policy provisions that cascade from them; this would ensure inclusiveness and co-operation from all stakeholders at the host-community level. It must be admitted that there will be challenges in effecting the recommended constitutional and statutory challenges as they require the affirmative votes of a two-thirds majority of members in each House of the National Assembly. The case of the Constitution amendments requires an additional criterion, a resolution in two-third of all the state Houses of Assembly (Constitution of the Federal Republic of Nigeria, 1999, section 9). In a country like Nigeria that is divided along with ethnic interests; it would be a tough task to win broad legislative approval for the suggested amendments. Assuming that it is possible to make the constitutional and statutory amendments, contentions are likely to continue along ethnic lines, and this might negatively impact their effective implementation as well as the peaceful and smooth operation of the solid mineral sector generally. Concerning inclusiveness, it is necessary to enforce the tenets of the Extractive Industries Transparency Initiative (EITI). EITI is the global standard to promote open and accountable management of oil, gas, and mineral resources. EITI is predicated on the belief that a country's natural resources are the commonwealth of its citizens. The EITI Standard mandates disclosure of information along the extractive industry value chain from the point of extraction, to the flow of revenue, and how the public benefits [19]. Nigeria has already signed up to EITI and has put in place the Nigerian Extractive Industries Transparency Initiative (NEITI). In 2003, Nigeria voluntarily signed up to EITI. On May 28, 2007, a specific law, the NEITI Act, was enacted to enforce the implementation of the initiative.

It is also necessary to offer assistance to artisanal and smallscale miners with regard to the formalization of their operations. 
While it has become much easier to register a company as a result of the improvements made by the Corporate Affairs Commission (CAC), a lot of artisanal and small-scale miners are either not well-informed about this opportunity or are too far removed from the capacities and facilities that are needed for registration of their businesses. To an extent, the legal and structural framework for assistance to artisanal and small-scale miners already exists as provided for under MMA 2007. However, there is a need to bring the bureaucracy and formal institutions closer to the grassroots to capture unregistered and unregulated activities. Any assistance may then be channeled through these bureaucracies and institutions. If the constitutional and statutory amendments recommended here are implemented, and administration of the solid minerals sector is decentralized, then States may adopt their structures with lessons from current practice.

More so, efforts should be made to build the capacity of regulatory and enforcement institutions to ensure effective implementation of environmental laws and policies.

Finally, investment incentives should not be adopted for their face value but considered pragmatically in terms of existing conditions and specific goals.

This study may be limited by the diverse reactions and evolving national realities, hence the need for ongoing evaluation and pragmatic response to operational challenges while implementing reforms in Nigeria's solid mineral sector. Further studies could examine these evolving national realities.

\section{Conflict of Interest}

The authors declare no conflict of interest.

\section{Reference}

[1] I. Aigbedion, S. Iyayi, "Diversifying Nigeria's petroleum industry" International Journal of Physical Sciences, 2(10), 263-270, 2007.

[2] World Commission on Environment and Development (WCED). "Our common future: The Brundtland report" Oxford: Oxford University Press, 1987.

[3] Nigeria Vision 20:2020. "Economic transformation blueprint. national planning commission" 2009. Retrieved from http://www.nationalplanningcycles.org/sites/default/files/planni ng_cycle_repository/nigeria/nigeria-vision-20-20-20.pdf

[4] UNDP; United Nations Development Programme. "Framework for harnessing the extractive industries for inclusive growth and development in Nigeria" United Nations Development Programme, 2014. Retrieved

https://www.undp.org/content/dam/nigeria/docs/IclusiveGrwth/ Framework\%20for\%20Harnessing\%20the $\% 20$ extractives $\% 20$ in $\% 20$ Nigeria.pdf

[5] K. Fayemi, "Nigeria's solid minerals sector: alternative investment opportunities" Chatham House The Royal Institute of International Affairs. p 1-9, 2016.

[6] E. Sampson, "Oil resource dependency; emerging threats and concerns" Zenith Economic Quarterly, 9(4), 30-38, 2013.

[7] D. Fearon, "Primary commodities exports and civil war" Journal of Conflict Resolution, 49(4), 483-507, 2005.

[8] T. Karl, "The paradox of plenty; oil booms and petrol states" Berkeley: University of California Press, 1997.

[9] Transformation Agenda. "The mid-term report of the transformation agenda 2011- 2013" 2013. Retrieved from https://www.slideshare.net/TransformNG/mid-term-report-ofthe-transformation-agenda-complete
[10] H. Adedeji, “Assessing the environmental impacts of inland sand mining in parts of Ogun State Nigeria" Ethiopian Journal of Environmental Studies and Management, 7(5), 478-487, 2014.

[11] D. Wapwera, "Abandoned mines, potential home for the people, a case study of Jos Plateau" Journal of Civil Engineering and Architecture, 9, 425-445, 2005.

[12] UNDP. "Managing Mining for Sustainable Development: A Sourcebook" Bangkok Regional Hub and PovertyEnvironment Initiative Asia-Pacific of UNDP and UN Environment, 2018.

[13] Minerals and Mining Act 2007 s. 23 - 30

[14] B. Baba, "Are traditional tax incentives needed to stimulate the Nigerian mining industry?" Tax Bites, 2018. Accessed from ww.pwc.com/ng

[15] Minerals and Mines Regulations (MMR) 2011 s. 154, 155, 156, 167 \& 169

[16] Land Use Act 1978 s. 1 \& 28(2)(c)

[17] UN. "Design and assessment of tax incentives in developing countries: selected issues and country experience" 2018. Accessed from www.un.orguplods $>2018 / 02$

[18] D. Teece, G. Pisano, A. Shuen, "Dynamic capabilities and strategic management" Strategic Management Journal, 18(7), 509-533.

[19] EITI, "Who We Are" (n.d). Accessed from eiti.org/who-we-are 